UDC 621.396 .969 .1

DOI: $10.26467 / 2079-0619-2020-23-2-8-19$

\title{
JOINT PROCESSING OF MEASUREMENTS IN A RANGEFINDER-DOPPLER MULTISTATIC RADAR SYSTEM
}

\author{
E.G. BORISOV ${ }^{1}$ \\ ${ }^{1}$ The Bonch-Bruevich Saint-Petersburg State University of Telecommunications, \\ ${ }^{1}$ St. Petersburg, Russia
}

\begin{abstract}
The article considers the option of organizing joint processing of radar information in a multistatic rangefinder - doppler radar system. The least-squares method is used to obtain analytical expressions for oblique ranges and radial velocities of targets during joint processing of range-finding measurements of various types. The obtained expressions for inclined ranges have some similarities with the secondary processing of radar information, with the only difference being that the weighting coefficients for the evaluated parameters are updated in the case of successive measurements as data are received, and in the case of joint processing, they depend on the number of positions and the number of measurements. It is shown that the joint processing of measurements of the inclined range, the sum of the distances, the radial velocity and the rate of change of the total range allows to increase the accuracy of measuring the location of an air object and the projections of its velocity vector on the axis of a rectangular coordinate system. The physical basis for increasing the accuracy of positioning is to use redundant measurements by processing the total ranges. The considered option of processing redundant measurements in a multistatic radar system does not require time to accumulate data, and the task of increasing accuracy is solved in one measurement cycle. The potential accuracy of determining the location of an air object for different values of the standard errors of the determination of rangefinding parameters in a multistatic radar system at various distances between positions has been calculated. For an arbitrary trajectory of an air object, simulationstatistical modeling was performed, which allows to obtain the mean square errors of determining the location and velocity vector of the air object. A gain is shown in the accuracy of determining the location and velocity vector of an air object in comparison with traditional algorithms for determining coordinates in long-range multistatic radar systems.
\end{abstract}

Key words: multistatic radar, rangefinding, sum of distances, radial speed, location, velocity vector, standard error.

\section{INTRODUCTION}

The topic of the coordinate measurement in the multistatic radar system (MRS) is covered in the remarkable amount of the Russian and foreign academic works. There are different variants of radar data (RD) processing in the radar and radionavigation systems described in them. The problem of the air-break object coordinates high-precision measurement is usually solved by increasing the radar system power potential (by increasing of the pilot signal power, high-speed aerial jet effect coefficient, radio set response, etc.), expanding of the pilot signal spectrum, using of the coherent integration. Nevertheless, the given approaches have a certain number of disadvantages. Increasing of the radar system power potential is problematic in certain cases for grounds of the structural system and operation. Involving the complex and spread spectrum signals allows to increase the range measuring accuracy, but while using of antenna systems with the measuring accuracy not high enough to measure the angular point the accuracy benefit is not considerable in some cases.

In the radio navigation tasks the required accuracy is achieved by the choice of the navigation space module algorithms advanced development and the best ground flight radio support facilities lo- 
cation; the location of the test station aboard the air-break object at the land-based distance from the devices of the user, which allows us to compute the differentional corrections by the precisely known base between the receiver units. The article [10] covers the procedure of signal acquisition and measurement in case of interference in the bistatic radar systems. The paper [11] considers in detail the variants of locating the radar and connection systems in the MRS which allow to maximize the connection between the signal and noise of every single channel; the geometric accuracy factor is contemporarily reduced to the minimum. The article [12] grounds the location accuracy tests increasing approaches in multilaterality systems; the works [13] and [14] cover the data reduction procedures in certain bistatic position couples of the radar system, [15] covers the location accuracy estimation in the conditions of the destabilizing factors, exposures, multiple-beam radiowave distribution, etc. The aircraft location accuracy involving differentially range-measurement and azimuthal measurements is researched in the work [16]. These approaches allow to increase the aircraft coordinates recognition accuracy in some cases, but the procedures of collaborative range and Doppler measurement reduction for coordinate measurement and object moving items are not covered in these works.

While the secondary radar information proceeding (SRIP) the optimum filtration procedures based on Kalman filter modifications, $\alpha, \beta$ filtration algorithms [19], spline procedures [20], etc. Trajectory data filtration procedures are limited by the object motion hypothesis and the considerable observation interval is required for measurement accumulation in the aim of the appropriate accuracy achievement while SRIP. The aircraft maneuver cycle performing cuts the filtration algorithms quality ratings down and requires some extra procedures in the aim of its sighting and filter beefing-up coefficients change.

While the ternary radar information proceeding (TRIP) arrangement the slope estimation accuracy is increased by blending of the different RS incentive index marks for one certain object with account for weight factors which are in inverse proportion to the relevant inadvertency dispersions [21].

The radar information complexation while TRIP by the incentive index marks blending based on the different RS measurement results requires a-priori knowledge of the object coordinates recognition inadvertency dispersions or undertaking of the reckoning procedure in the aim of their estimation.

The purpose of this article is to develop the cooperative measurement proceeding methods and algorithms in the range measurement doppler MRS in the aim of the aircraft location investigation and the definition of its speed vector projection to the rectangular coordinate system centreline.

\section{THE AIRCRAFT POSITION FINDING INVOLVING THE RANGE MEASUREMENT}

The works $[1,2]$ show that cooperative radar information processing in the MRS is the most valuable one as it allows to derive the potentially larger information content from the current awareness. The feature of such a data proceeding approach is that all the positions are able to receive the fended signals in the area of responsibility while being irradiated by any relaying position. The cooperative data proceeding allows to make the redundant measurements in the system; this is the physical basis of the coordinate recognition accuracy increasing. If the quantity of the range measurement items (inclined ranges and distance amounts) being estimated is more than the number of required values, there will be changes in the MRS which might be used for the line-of sight range recognition accuracy increasing as relating to every single coordinate.

The synergy of spacely spread-out RS with circularly disposed antenna arrays or multiple-beam active phased array antennas scanning the defined area in the azimuthal and elevation plane is the variant of MRS for the cooperative data proceeding. Involving the low directional antennas is also possible in case of non-requiring the considerable range according to the mission requirements.

Let us consider the summarily- range measurement radar system consisting of the send-receive positions $\mathrm{N}$. The measurements of slant $R_{1}, R_{2} \ldots R_{N}$ and summarized ranges $R_{\Sigma 12}, R_{\Sigma 21}, R_{\Sigma N(N-1)}$ are conducted in this system. 
There are $N$ range measurements and $N(N-1)$ distance amounts measurements possible in such a system, which provides us with $\mathrm{n}=\mathrm{N}^{2}$ measurements of the estimated parameter. Let us write the scalar algebraic coupled equations, according to the considered range measurements.

$$
\left\{\begin{array}{l}
\left\{\begin{array}{l}
\hat{R}_{1}=1 \cdot \tilde{R}_{1}+0 \cdot \tilde{R}_{2}+0 \cdot \tilde{R}_{3}+\ldots+0 \cdot \tilde{R}_{N}, \\
\hat{R}_{2}=0 \cdot \tilde{R}_{1}+1 \cdot \tilde{R}_{2}+0 \cdot \tilde{R}_{3}+\ldots+0 \cdot \tilde{R}_{N}, \quad N \text { измерений } \\
\vdots \\
\hat{R}_{N}=0 \cdot \tilde{R}_{1}+0 \cdot \tilde{R}_{2}+0 \cdot \tilde{R}_{3}+\ldots+1 \cdot \tilde{R}_{N(N-1)},
\end{array}\right. \\
\left\{\begin{array}{l}
\hat{R}_{\Sigma 12}=1 \cdot \tilde{R}_{1}+1 \cdot \tilde{R}_{2}+0 \cdot \tilde{R}_{3}+\ldots+0 \cdot \tilde{R}_{N(N-1)}, \\
\hat{R}_{\Sigma 21}=1 \cdot \tilde{R}_{1}+1 \cdot \tilde{R}_{2}+0 \cdot \tilde{R}_{3}+\ldots+0 \cdot \tilde{R}_{N(N-1)}, \\
\hat{R}_{\Sigma 13}=1 \cdot \tilde{R}_{1}+0 \cdot \tilde{R}_{2}+1 \cdot \tilde{R}_{3}+\ldots+0 \cdot \tilde{R}_{N(N-1)}, \\
\hat{R}_{\Sigma 31}=1 \cdot \tilde{R}_{1}+0 \cdot \tilde{R}_{2}+1 \cdot \tilde{R}_{3}+\ldots+0 \cdot \tilde{R}_{N(N-1)}, \\
\vdots \\
\hat{R}_{\Sigma N(N-1)}=0 \cdot \tilde{R}_{1}+0 \cdot \tilde{R}_{2}+0 \cdot \tilde{R}_{3}+\ldots+1 \cdot \tilde{R}_{N(N-1)},
\end{array}\right.
\end{array} .\right.
$$

where $\hat{R}_{i} i=\overline{1, N}$ are the slant ranges to the aircraft resp in relation to the $i$ position, and $\hat{R}_{\Sigma i j}$ at $i, j=\overline{1, N}, i \neq j$ are the summarized ranges to the aircraft in relation to the $i$ and $j$ positions. In the matrix form the coupled equations will take the form of

$$
\hat{z}=A \widetilde{Z}
$$

where $\hat{z}^{T}=\left\|\hat{R}_{1}, \hat{R}_{2} \ldots \hat{R}_{N}, \hat{R}_{\Sigma 12}, \hat{R}_{\Sigma 21}, \hat{R}_{\Sigma 13}, \ldots, \hat{R}_{N(N-1) i j}\right\|$ is the matrix (row-vector) of the fundamental measurements; their size is $1 \times n$;

$A$ is the coefficient matrix of the indeterminates; their size is $N \times n$; $\tilde{Z}^{T}=\left\|\tilde{R}_{1}, \tilde{R}_{2} \ldots \tilde{R}_{N}\right\|$ is the matrix (row-vector) of the required range estimations; their size is $1 \times N$.

The results of the certain measurements might not be used in the real setting, for instance, due to the air object dropping. To take the factor into account, let us interpolate the scalar matrix; its size is $n \times n \quad \Lambda=\operatorname{diag}\left[\lambda_{1}, \lambda_{i}, \ldots, \lambda_{n}\right], i=\overline{1, n}$ this matrix takes into account the presence or absence of the relevant measurements. If the measurement $i$ is used while handling the problem, then $\lambda_{i}=1$, if it is not used, then $\lambda_{i}=0$. Involving the least squares method in (2), we will obtain [22, 23]

$$
\hat{Z}=\left(A^{T} \Lambda W A\right)^{-1} A^{T} \Lambda W Z,
$$

where $\mathrm{W}$ is the dispersion matrix of the relevant range-measurement items; its size is $n \times n$.

We shall obtain the covariance inadvertency matrix for the case of dispersion range measurement uniformly precise measurements $\sigma_{R}^{2}=\sigma_{0}^{2}$ and distance amounts $\sigma_{R \Sigma}^{2}=\sigma_{0}^{2}$. The matrix diagonal element are the range measurement standard error dispersions while the cooperative data proceeding in MRS

$$
W_{R C}^{2}=\sigma_{0}^{2}\left(A^{T} W A\right)^{-1}
$$


The solution (3) corresponds to Hauss-Markoff theorem of the effective scalar estimations, because the estimation for the certain system of the scalar argument function relation has the minimal dispersions among the multitude of the scalar bias-free estimations for any error equations and in case of the scalar correspondence to the required items. This solution is reasonable in case of fulfilling the Hauss-Markoff conditions: the observation model is scalar by the coefficients, is rated in a correct way and envelops the additive component, the changes are not correlated, expectation function of the evaluated process is zero.

In case of the four-position system, the conjugated coefficient matrix for indeterminate items will take the form of:

$$
A^{T}=\left\|\begin{array}{|llllllllllllllll}
1 & 0 & 0 & 0 & 1 & 1 & 1 & 1 & 1 & 1 & 0 & 0 & 0 & 0 & 0 & 0 \\
0 & 1 & 0 & 0 & 1 & 1 & 0 & 0 & 0 & 0 & 1 & 1 & 1 & 1 & 0 & 0 \\
0 & 0 & 1 & 0 & 0 & 0 & 1 & 1 & 0 & 0 & 1 & 1 & 0 & 0 & 1 & 1 \\
0 & 0 & 0 & 1 & 0 & 0 & 0 & 0 & 1 & 1 & 0 & 0 & 1 & 1 & 1 & 1
\end{array}\right\|
$$

With regard to (3) and (5) we shall obtain the range amounts while the joint processing of measurement:

$$
\begin{aligned}
\tilde{R}_{1}= & \frac{1}{65}\left(11 \hat{R}_{1}-2 \hat{R}_{2}-2 \hat{R}_{3}-2 \hat{R}_{4}+9 \hat{R}_{\Sigma 12}+9 \hat{R}_{\Sigma 21}+9 \hat{R}_{\Sigma 13}+9 \hat{R}_{\Sigma 31}+\right. \\
& \left.+9 \hat{R}_{\Sigma 14}+9 \hat{R}_{\Sigma 41}-4 \hat{R}_{\Sigma 23}-4 \hat{R}_{\Sigma 32}-4 \hat{R}_{\Sigma 24}-4 \hat{R}_{\Sigma 42}-4 \hat{R}_{\Sigma 34}-4 \hat{R}_{\Sigma 43}\right), \\
\tilde{R}_{2}= & \frac{1}{65}\left(11 \hat{R}_{2}-2 \hat{R}_{1}-2 \hat{R}_{3}-2 \hat{R}_{4}+9 \hat{R}_{\Sigma 12}+9 \hat{R}_{\Sigma 21}-4 \hat{R}_{\Sigma 13}-4 \hat{R}_{\Sigma 31}-\right. \\
& \left.-4 \hat{R}_{\Sigma 14}-4 \hat{R}_{\Sigma 41}+9 \hat{R}_{\Sigma 23}+9 \hat{R}_{\Sigma 32}+9 \hat{R}_{\Sigma 24}+9 \hat{R}_{\Sigma 42}-4 \hat{R}_{\Sigma 34}-4 \hat{R}_{\Sigma 43}\right), \\
\tilde{R}_{3}= & \frac{1}{65}\left(11 \hat{R}_{3}-2 \hat{R}_{2}-2 \hat{R}_{1}-2 \hat{R}_{4}-4 \hat{R}_{\Sigma 12}-4 \hat{R}_{\Sigma 21}+9 \hat{R}_{\Sigma 13}+9 \hat{R}_{\Sigma 31}-\right. \\
& \left.-4 \hat{R}_{\Sigma 14}-4 \hat{R}_{\Sigma 41}+9 \hat{R}_{\Sigma 23}+9 \hat{R}_{\Sigma 32}-4 \hat{R}_{\Sigma 24}-4 \hat{R}_{\Sigma 42}+9 \hat{R}_{\Sigma 34}+9 \hat{R}_{\Sigma 43}\right), \\
\tilde{R}_{4}= & \frac{1}{65}\left(11 \hat{R}_{4}-2 \hat{R}_{2}-2 \hat{R}_{3}-2 \hat{R}_{1}-4 \hat{R}_{\Sigma 12}-4 \hat{R}_{\Sigma 21}-4 \hat{R}_{\Sigma 13}-4 \hat{R}_{\Sigma 31}+\right. \\
& \left.+9 \hat{R}_{\Sigma 14}+9 \hat{R}_{\Sigma 41}-4 \hat{R}_{\Sigma 23}-4 \hat{R}_{\Sigma 32}+9 \hat{R}_{\Sigma 24}+9 \hat{R}_{\Sigma 42}+9 \hat{R}_{\Sigma 34}+9 \hat{R}_{\Sigma 43}\right) .
\end{aligned}
$$

While measuring the doppler frequency shifts as regard to every $F_{\dot{R}}$. position and the doppler frequency drift, derived by the rate of change of the total range $\boldsymbol{F}_{\dot{\boldsymbol{R}} \boldsymbol{\Sigma} \boldsymbol{i}}$ we might obtain the radial speed amounts in analogy with (6), where it is necessary to use $\dot{R}_{i}=0.5 \lambda_{i} F_{\dot{R} i}$ and $\dot{R}_{\Sigma i j}=\dot{R}_{i}+\dot{R}_{j}=\lambda_{i} F_{\dot{R} \Sigma i}$ instead of the ranges and distance amounts.

The covariance range measurement inadvertency matrix in case of uniformly precise measurements and in case of $\boldsymbol{\sigma}_{\boldsymbol{R}}^{2}=\boldsymbol{\sigma}_{\boldsymbol{R} \Sigma}^{2}=\boldsymbol{\sigma}_{\mathbf{0}}^{2}$ and at $\boldsymbol{\sigma}_{\boldsymbol{R} \Sigma}^{2}=4 \boldsymbol{\sigma}_{\mathbf{0}}^{2}, \boldsymbol{\sigma}_{\boldsymbol{R} \boldsymbol{\Sigma}}^{2}=16 \sigma_{0}^{2}$ according to (4) and (5) accordingly will take a form of 


$$
W_{R C 1}=\frac{1}{65}\left\|\begin{array}{|llll}
11 & -2 & -2 & -2 \\
-2 & 11 & -2 & -2 \\
-2 & -2 & 11 & -2 \\
-2 & -2 & -2 & 11
\end{array}\right\| \sigma_{0}^{2}, \quad W_{R C 2}=\frac{1}{16}\left\|\begin{array}{cccc}
7 & -1 & -1 & -1 \\
-1 & 7 & -1 & -1 \\
-1 & -1 & 7 & -1 \\
-1 & -1 & -1 & 7
\end{array}\right\| \sigma_{0}^{2}, W_{R C 3}=\frac{1}{35}\left\|\begin{array}{cccc}
26 & -2 & -2 & -2 \\
-2 & 26 & -2 & -2 \\
-2 & -2 & 26 & -2 \\
-2 & -2 & -2 & 26
\end{array}\right\| \sigma_{0}^{2}
$$

In the aim of orthogonal coordinates recognition let us consider $\mathrm{N}$ non-linear equations which link the aircraft required coordinates,

$$
R_{i k}=\sqrt{\left(X-x_{i}\right)^{2}+\left(Y-y_{i}\right)^{2}+\left(H-h_{i}\right)^{2}},
$$

where $x_{i}, y_{i}, h_{i}$ are the RS location coordinates.

The orthogonal coordinates might be recognized by using either numerical methods or least squares

$$
Z_{R}=\left(A_{R}^{T} A_{R}\right)^{-1} A_{R}^{T} Z_{R},
$$

in this case

$$
A_{R}=\left\|\begin{array}{ccc}
\Delta x_{21} & \Delta y_{21} & \Delta h_{21} \\
\Delta x_{31} & \Delta y_{31} & \Delta h_{31} \\
\Delta x_{41} & \Delta y_{41} & \Delta h_{41} \\
\vdots & \vdots & \vdots \\
\Delta x_{N 1} & \Delta y_{N 1} & \Delta h_{N 1}
\end{array}\right\|, z_{R}=0.5\left\|\begin{array}{c}
R_{1}^{2}-R_{2}^{2}-d_{1}^{2}+d_{2}^{2} \\
R_{1}^{2}-R_{3}^{2}-d_{1}^{2}+d_{3}^{2} \\
R_{1}^{2}-R_{4}^{2}-d_{1}^{2}+d_{4}^{2} \\
\vdots \\
R_{1}^{2}-R_{N}^{2}-d_{1}^{2}+d_{N}^{2}
\end{array}\right\|,
$$

where $\Delta x_{i j}=x_{i}-x_{j}, \Delta y_{i j}=y_{i}-y_{j}, \Delta h_{i j}=h_{i}-h_{j}$, a $d_{i}=\sqrt{x_{i}^{2}+y_{i}^{2}+h_{i}^{2}}$ is the distance from the origin of coordinates to the i-position.

\section{THE POSITIONING OF THE AIRCRAFT SPEED VECTOR PROJECTION ON THE CARTESIAN-COORDINATE SYSTEM AXIS}

Let us perform a differentiation of (9) in time in the aim of aircraft speed vector amount recognition on the cartesian-coordinate system axis

$$
\dot{Z}_{R}=\left[\left(A_{R}{ }^{T} A_{R}\right)^{-1}\left(\dot{A}_{R}{ }^{T} z_{R}+A^{T} \dot{z}_{R}\right)-\left(A_{R}{ }^{T} A_{R}\right)^{-1}\left(\dot{A}_{R}{ }^{T} A_{R}+A_{R}{ }^{T} \dot{A}_{R}\right)\left(A_{R}{ }^{T} A_{R}\right)^{-1} A_{R}{ }^{T} z_{R}\right],
$$

where

$$
\dot{A}_{R}=\left\|\begin{array}{ccc}
\Delta \dot{x}_{\mathrm{N} 1} & \Delta \dot{y}_{N 1} & \Delta \dot{h}_{N 1} \\
\Delta \dot{x}_{\mathrm{N} 2} & \Delta \dot{y}_{N 1} & \Delta \dot{h}_{N 2} \\
\Delta \dot{x}_{\mathrm{N} 3} & \Delta \dot{y}_{N 1} & \Delta \dot{h}_{N 3} \\
& & \\
\Delta \dot{x}_{\mathrm{N}(N-1)} & \Delta \dot{y}_{N(N-1)} & \Delta \dot{h}_{N(N-1)}
\end{array}\right\|, \dot{z}_{R}=\left\|\begin{array}{c}
R_{1} \dot{R}_{1}-R_{N} \dot{R}_{N}-d_{1} \dot{d}_{1}+d_{N} \dot{d}_{N} \\
R_{2} \dot{R}_{2}-R_{N} \dot{R}_{N}-d_{2} \dot{d}_{2}+d_{N} \dot{d}_{N} \\
R_{3} \dot{R}_{3}-R_{N} \dot{R}_{N}-d_{3} \dot{d}_{3}+d_{N} \dot{d}_{N} \\
\vdots \\
R_{N-1} \dot{R}_{N-1}-R_{N} \dot{R}_{N}-d_{N-1} \dot{d}_{N-1}+d_{N} \dot{d}_{N}
\end{array}\right\|,
$$


$\Delta \dot{x}_{i j}=\dot{x}_{i}-\dot{x}_{j}, \Delta \dot{y}_{i j}=\dot{y}_{i}-\dot{y}_{j}, \Delta \dot{h}_{i j}=\dot{h}_{i}-\dot{h}_{j}$ is the distance change speed between the positions by the relevant orthogonal coordinates $\dot{x}_{i}, \dot{y}_{i}, \dot{h}_{i}$ are the RS location change speeds, $\dot{d}_{i}=\frac{\left(x_{i} \dot{x}_{i}+y_{i} \dot{y}_{i}+h_{i} \dot{h}_{i}\right)}{d_{i}}$ is the RS moving-off speed from the origin of coordinates.

In case of the stationary position, $\dot{x}_{i}=0, \dot{y}_{i}=0, \dot{h}_{i}=0$, (11) will take a simpler form:

$$
\begin{gathered}
\dot{Z}_{R}=\left(A_{R}{ }^{T} A_{R}{ }^{-1}\right) A_{R}{ }^{T} \dot{Z}_{R}, \\
\dot{z}_{R}=\left\|\begin{array}{c}
R_{1} \dot{R}_{1}-R_{N} \dot{R}_{N} \\
R_{2} \dot{R}_{2}-R_{N} \dot{R}_{N} \\
R_{3} \dot{R}_{3}-R_{N} \dot{R}_{N} \\
\vdots \\
R_{N-1} \dot{R}_{N-1}-R_{N} \dot{R}_{N}
\end{array}\right\|,
\end{gathered}
$$

Based on (9), (10), (12), (13), the aircraft speed vector coordinate and projection recognition on the cartesian-coordinate system axis is possible in a single data proceeding cycle without considering the limits on the motion hypothesis of the object location. We might recognize the whole aircraft speed vector $V=\sqrt{\dot{X}^{2}+\dot{Y}^{2}+\dot{H}^{2}}$ basing on (12) and (13).

\section{THE OBJECT POSITION AND ITS SPEED VECTOR ACCURACY ESTIMATION}

Figures 1 and 2 demonstrate the results of calculating the potential aircraft location recognition accuracy in the fourposition RS. The distance from the origin of coordinates to every RS is $d=25$. The resulting error of the aircraft spatial variable location recognition is expressed by the complete correlation matrix [24]

$$
\sigma=\sqrt{\operatorname{tr}\left[\left(D^{T} W^{-1} D\right)^{-1}\right]}
$$

where $t r$ is the matrix trace (the amount of the diagonal elements), and $\mathrm{D}$ is the matrix of the partial differential coefficient in the form of

$$
D=\left\|\begin{array}{lll}
\frac{\partial R_{1}}{\partial X} & \frac{\partial R_{1}}{\partial Y} & \frac{\partial R_{1}}{\partial H} \\
\frac{\partial R_{2}}{\partial X} & \frac{\partial R_{2}}{\partial Y} & \frac{\partial R_{2}}{\partial H} \\
\vdots & \vdots & \vdots \\
\frac{\partial R_{N}}{\partial X} & \frac{\partial R_{N}}{\partial Y} & \frac{\partial R_{N}}{\partial H}
\end{array}\right\| .
$$

Range measurement quadratic mean errors were thought to be equal to $\sigma_{0}=50 \mathrm{~m}$. The numerical calculations were conducted while the aircraft moving in a circumferential direction relating to the origin of coordinates on the constant altitude and range $\mathrm{R}_{0}$. The amounts of location recognition quadratic mean errors (QME), derived for the different measurement accuracy, are denoted by some numbers in Figures 1 and 2: 1 - the range - measurement system in case of uniformly precise measurement without their cooperative proceeding;2, 3, 4 - the cooperative measurement proceeding resp in case of $\sigma_{R}^{2}=\sigma_{0}^{2}$ и $\sigma_{R \Sigma}^{2}=16 \sigma_{0}^{2}, \sigma_{R}^{2}=\sigma_{0}^{2}$ и $\sigma_{R \Sigma}^{2}=4 \sigma_{0}^{2}, \sigma_{R}^{2}=\sigma_{0}^{2}$ и $\sigma_{R \Sigma}^{2}=\sigma_{0}^{2}$. 
There are the results obtained from the aircraft position and the speed vector modeling for the considered MRS recognition in Figures 3 and 4. The primary data measurement inadvertencies are subordinated to the normal statistical law with the zero mean and are tied functionally to the ratio of signal -to- noise. The aircraft reference coordinates are chosen as $\mathrm{X}=0, \mathrm{Y}=1.5 \mathrm{~d}, \mathrm{H}=0.2 \mathrm{~d}$. While changing the aircraft path the fundamental measurement recognition QME reached the range of $\sigma_{R}=5 \div 60 \mathrm{~m}, \sigma_{R \Sigma}=5 \div 60 \mathrm{~m}$ at the radial speed of $\sigma_{\dot{R}}=2 \div 6 \mathrm{~m} / \mathrm{s}$, the summarized range change speed of $\sigma_{\dot{R} \Sigma}=2 \div 10 \mathrm{~m} \mathrm{~m} / \mathrm{s}$.

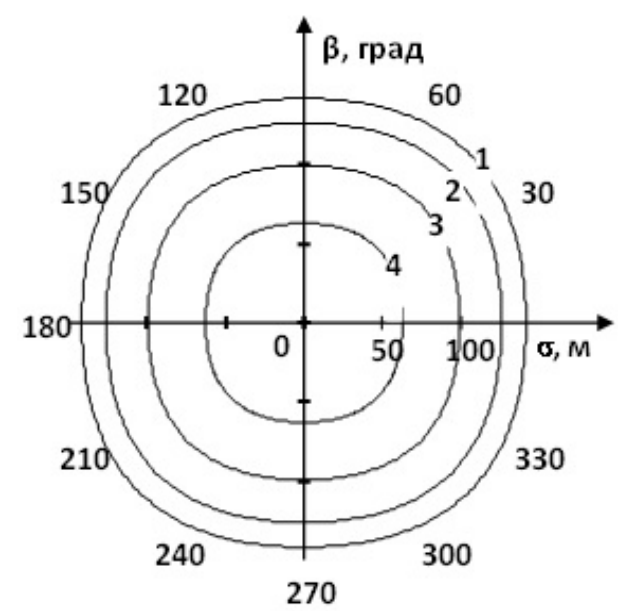

Fig. 1. The potential accuracy of determining the location of an air object at $\mathrm{R}_{0}=4 \mathrm{~d}$

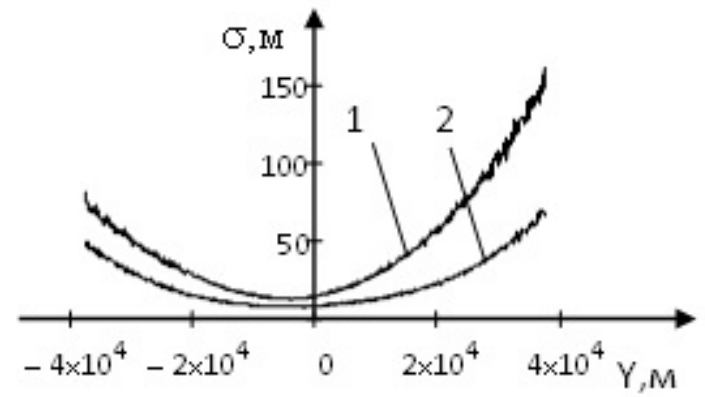

Fig. 3. The standard error of determining the location of an air object

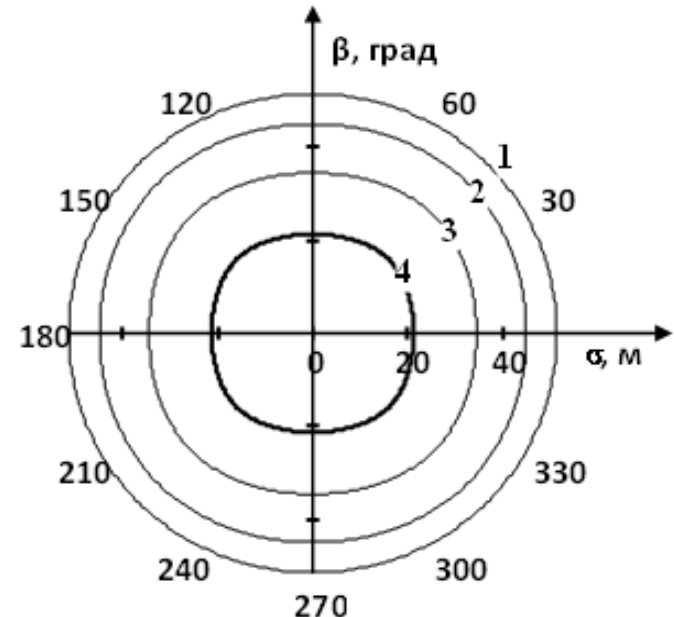

Fig. 2. The potential accuracy of determining the location of an air object at $R_{0}=0.5 \mathrm{~d}$

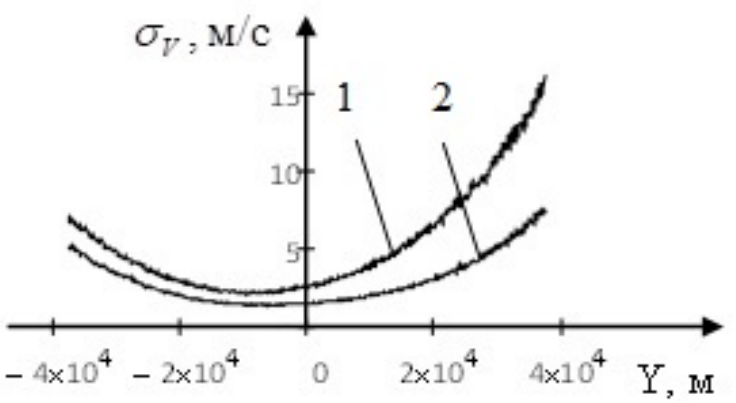

Fig. 4. The standard error of determining the projection of the velocity vector of an air object

That is what denoted by the numbers in Figure. 3:

1 - the aircraft position QME;

2 - the aircraft position QME in case of cooperative measurement proceeding;

and Figure 4:

1 - the aircraft speed vector QME;

2 - the aircraft speed vector QME in case of cooperative measurement proceeding.

\section{CONCLUSION}

The formulas for line-of-sight ranges and radial speeds of the items in case of the cooperative measurement proceeding in range-measurement doppler multilocational radar system are derived. The recognition of the object location orthogonal coordinates and its movement parameters is possible due to these formulas. 
The principal feature of the data redundancy in MRS is that the considerable amount of time for data accumulation is not required, and the problem of increasing the accuracy is handled for the single measurement cycle.

The formulas for line-of-sight ranges are similar to the secondary radar data proceeding procedures. The only contrast is that the weight coefficient of the estimated parameters are brought up to date as soon as the data is available in case of QME, and depend on the number of positions and the measurements quantity in case of the cooperative data proceeding.

In the context of the considered instance the potential accuracy of the location recognition is $1.12-2.25$ times for the small-based system and $2.3-4.1$ for the large-based one. The benefit from the location estimation accuracy and the aircraft speed vector on the cartesian-coordinate system axis is $1.2-2.8$ times in the context of the considered instance for the aircraft certain path.

\section{REFERENCES}

1. Chernyak, V.S. (1993). Mnogopozitsionnaya radiolokatsiya [Multiposition Radar]. Moscow: Radio i svyaz, 416 p. (in Russian)

2. Chernyak, V.S., Zaslavskiy, L.P. and Osipov, L.V. (1987). Multiposition radar stations and systems. Zarubezhnaya radioelektronika, no. 1, pp. 9-69. (in Russian)

3. Zaytsev, D.V. (2007). Mnogopozitsionnyye radiolokatsionnyye sistemy. Metody i algoritmy obrabotki informatsii v usloviyakh pomekh [Multiposition Radar Systems. Methods and Algorithms for Processing Information in the Interference Condition]. Moscow: Radiotekhnika, 114 p. (in Russian)

4. Kirsanov, E.A. and Sirota, A.A. (2012). Obrabotka informatsii v prostranstvennoraspredelennykh sistemakh radiomonitoringa: statisticheskiy i neyrosetevoy podkhody [Information Processing in Spatially Distributed Radio Monitoring Systems: Statistical and Neural Network Approaches]. Moscow: FIZMATLIT, 344 p. (in Russian)

5. Kondratev, V.S., Kotov, A.F. and Markov, L.N. (1986). Mnogopozitsionnyye radiotekhnicheskiye sistemy [Multiposition Radio Engineering Systems], in Tsvetnova V.V. (Ed.). Moscow: Radio i svyaz, 264 p. (in Russian)

6. Kondrashov, V.I. and Kondrashov, Ya.V. (2004). Printsipy i struktury mobilnykh, lokalnykh, mnogopozitsionnykh navigatsionno-posadochnykh aviatsionnykh radiosistem nazemnogo bazirovaniya [Principles and Structures of Mobile, Local, Multi-Position Navigation and Landing Aviation Ground-Based Radio Systems]. Nauchnyy vestnik MGTU GA, no. 76, pp. 84-92. (in Russian)

7. Zatuchnyy, D.A. (2017). Povysheniye tochnosti opredeleniya mestopolozheniya vozdushnykh sudov na osnove ucheta oshibok 1 i 2 roda pri vybore nabora sputnikov [Improving the accuracy of Determining the Location of Aircraft Based on Errors of the 1st and 2nd Kind when Choosing a Set of Satellites]. Vestnik Sankt-Peterburgskogo gosudarstvennogo universiteta grazhdanskoy aviatsii, no. 1 (14), pp. 39-46. (in Russian)

8. Zatuchny, D.A., Maslov, A.K. and Erich, M.Y. (2019). Choice of topology of location of surface backer-ups flights for improvement of exactness of exposure of navigation error. Informatsiya $\mathrm{i}$ svyaz, no. 4, pp. 169-173. DOI: 10.34219/2078-8320-2019-10-4-169-173. (in Russian)

9. Shestakov, I.N. (2006). Increase of accuracy of positioning of mobile objects with application of several reception devices GPS onboard of aircrafts. Nauchnyy Vestnik MGTU GA, no. 107, pp. 180-189. (in Russian)

10. Ji, C., Shen, M., Liang, C., Wu, D. and Zhu, D.-Y. (2017). An efficient adaptive clutter compensation algorithm for bistatic airborne radar based on improved OMP application. Progress in Electromagnetics Research M, vol. 59, pp. 203-212. DOI:10.2528/PIERM17060801

11. Kilani, M.B., Gagnon, G. and Gagnon, F. (2018). Multistatic radar placement optimization for cooperative radar-communication systems. IEEE Communications Letters, vol. 22, issue 8, pp. 1576-1579. DOI: 10.1109/LCOMM.2018.2837913 
12. Xu, Z., He, D., Tang, Y. and Li, J. (2015). A MLAT algorithm based on target pressure altitude. IEEE International Conference on Mechatronics and Automation (ICMA), pp. 1800-1804. DOI:10.1109 / ICMA.2015.7237759

13. Webster, T. and Higgins, T. (2015). Detection aided multistatic velocity back projection for passive radar. IEEE International Conference on Acoustics, Speech and Signal Processing (ICASSP), pp. 5580-5584. DOI: 10.1109/ICASSP.2015.7179039

14. Webster, T, Higgins, T. and Mokole, E.L. (2016). Passive multistatic radar experiment using WiMAX signals of opportunity. Part 2: Multistatic velocity backprojection. Radar Sonar \& Navigation IET, vol. 10, no. 2, pp. 248-255. DOI: 10.1049/iet-rsn.2015.0021

15. Tong, J., Gaoming, H., Wei, T. and Huafu, P. (2019). Cramér-Rao lower bound analysis for stochastic model based target parameter estimation in multistatic passive radar with direct-path interference. IEEE Access, vol. 7, pp. 106761-106772. DOI: 10.1109/ACCESS.2019.2926353

16. Wang, J., Qin, Z., Bi, Y., Wei, S. and Luo, F. (2019). Target localisation in multistatic radar using br, tdoa, and aoa measurements. The Journal of Engineering, vol. 2019, issue 19, pp. 6052-6056. DOI: 10.1049/joe.2019.0128

17. Merkulov, V.I. and Sadovskiy, P.A. (2018). Estimation of distance and its derivatives in the bistatic passive radar location system. SPIIRAS Proceedings, no. 1 (56), pp. 122-143. DOI: 10.15622/sp.56.6. (in Russian)

18. Verba, V.S., Merkulov, V.I. and Sadovskiy, P.A. (2015). Multiband radars. Multitarget tracking challenges. Radio Engineering, no. 5, pp. 37-51. Available at: https://www.radiovega.su/ jour/article/view/44?locale=ru_RU (accessed 01.15.2020). DOI: 10.7463/rdopt.0515.0817948. (in Russian)

19. Kuzmin, S.Z. (1986). Osnovy proyektirovaniya sistem tsifrovoy obrabotki radiolokatsionnoy informatsii [Fundamentals of Designing Systems for Digital Processing of Radar Information]. Moscow: Radio i svyaz, 352 p. (in Russian)

20. Vasilev, K.K., Pavlygin, E.D. and Gutorov, A.S. (2016). Building maneuvering targets trajectories on the basis of splines and kalman filters. Automation of Control Processes, no. 1 (43), pp. 67-75. (in Russian)

21. Okhrimenko, A.E. (1990). Osnovy obrabotki i peredachi informatsii [Processing and Transmitting Information Basics]. Minsk: Voyenizdat, 180 p. (in Russian)

22. Borisov, E.G., Mashkov, G.M. and Turnetsky, L.S. (2013). Increase of accuracy of determination of coordinates of the purpose at realization of cooperative processing in the multiitem radar-tracking system. Journal Radioengineering, no. 5, pp. 4-9. (in Russian)

23. Borisov, E., Mashkov, G. and Fokin, G. (2016). Experimental validation of multipoint joint processing of range measurements via software-defined radio testbed. 18th International Conference on Advanced Communication Technology (ICACT), Pyeongchang, pp. 268-273. DOI: 10.1109/ICACT.2016.7423356. (in Russian)

24. Shebshaevich, V.S., Dmitriev, P.P. and Ivantsevich, N.V. (1993). Setevyye sputnikovyye radionavigatsionnyye sistemy [Network Satellite Radio Navigation Systems ], in Shebshayevicha V.S. (Ed.). 2nd ed., rev. and add. Moscow: Radio i svyaz, 408 p. (in Russian)

25. Shirman, Y.D. (1970). Teoreticheskiye osnovy radiolokatsii: uchebnoye posobiye dlya VUZ [Theoretical Basics of Radar: Tutorial for Universities]. Moscow: Sovetskoye radio, $560 \mathrm{p}$. (in Russian) 


\title{
INFORMATION ABOUT THE AUTHOR
}

Evgeny G. Borisov, Doctor of Technical Sciences, Associate Professor, Chief Specialist in the Implementation of Investment and Scientific and Technical Projects, The Bonch-Bruevich SaintPetersburg State University of Telecommunications, begspb1967@mail.ru.

\section{СОВМЕСТНАЯ ОБРАБОТКА ИЗМЕРЕНИЙ В ДАЛЬНОМЕРНО-ДОПЛЕРОВСКОЙ МНОГОПОЗИЦИОННОЙ РАДИОЛОКАЦИОННОЙ СИСТЕМЕ}

\author{
Е.Г. Борисов ${ }^{1}$ \\ ${ }^{1}$ Санкт-Петербургский государственный университет \\ телекоммуникаций им. проф. М.А. Бонч-Бруевича, г. Санкт-Петербург, Россия
}

В статье рассматривается вариант организации совместной обработки радиолокационной информации в многопозиционной дальномерно - доплеровской радиолокационной системе. Методом наименьших квадратов получены аналитические выражения для наклонных дальностей и радиальных скоростей целей при совместной обработке дальномерных измерений различных типов. Полученные выражения для наклонных дальностей имеют определённое сходство с процедурами вторичной обработки радиолокационной информации с той лишь разницей, что весовые коэффициенты при оцениваемых параметрах в случае проведения последовательных измерений обновляются по мере поступления данных, а в случае совместной обработки зависят от числа позиций и количества измерений. Показано, что совместная обработка измерений наклонной дальности, сумм расстояний, радиальной скорости и скорости изменения суммарной дальности позволяет повысить точность измерения местоположения воздушного объекта и проекций его вектора скорости на оси прямоугольной системы координат. Физическая основа повышения точности определения местоположения заключается в использовании избыточных измерений за счёт обработки суммарных дальностей. Рассматриваемый вариант обработки избыточных измерений в многопозиционной радиолокационной системе не требует времени для накопления данных, а задача повышения точности решается за один цикл проведения измерений. Проведены расчеты потенциальной точности определения местоположения воздушного объекта для различного значения среднеквадратических ошибок определения дальномерных параметров в многопозиционной радиолокационной системе при различных расстояниях между позициями. Для произвольной траектории воздушного объекта проведено имитационно статистическое моделирование, позволяющее получить значения среднеквадратических ошибок определения местоположения и вектора скорости воздушного объекта. Показан выигрыш в точности определения местоположения и вектора скорости воздушного объекта по сравнению с традиционными алгоритмами определения координат в дальномерных многопозиционных радиолокационных системах.

Ключевые слова: многопозиционная радиолокация, дальномерные, суммарно - дальномерные, радиальная скорость, местоположение, вектор скорости, среднеквадратическая ошибка.

\section{СПИСОК ЛИТЕРАТУРЫ}

1. Черняк В.С. Многопозиционная радиолокация. М.: Радио и связь, 1993. 416 с.

2. Черняк В.С., Заславский Л.П., Осипов Л.В. Многопозиционные радиолокационные станции и системы // Зарубежная радиоэлектроника. 1987. № 1. С. 9-69.

3. Зайцев Д.В. Многопозиционные радиолокационные системы. Методы и алгоритмы обработки информации в условии помех. М.: Радиотехника, 2007. 114 с.

4. Кирсанов Э.А., Сирота А.А. Обработка информации в пространственно-распределённых системах радиомониторинга: статистический и нейросетевой подходы. М.: ФИЗМАТЛИТ, 2012. 344 с.

5. Кондратьев В.С., Котов А.Ф., Марков Л.Н. Многопозиционные радиотехнические системы / Под ред. В.В. Цветнова. М.: Радио и связь, 1986. 264 с. 
6. Кондрашов В.И., Кондрашов Я.В. Принципы и структуры мобильных, локальных, многопозиционных навигационно-посадочных авиационных радиосистем наземного базирования // Научный Вестник МГТУ ГА, серия Радиофизика и радиотехника. 2004. № 76. С. 84-92.

7. Затучный Д.А. Повышение точности определения местоположения воздушных судов на основе учёта ошибок 1 и 2 рода при выборе набора спутников // Вестник СанктПетербургского государственного университета гражданской авиации. 2017. № 1 (14). С. 39-46.

8. Затучный Д.А., Маслов А.К., Эрич М.Й. Выбор топологии расположения наземных средств обеспечения полетов для улучшения точности выявления навигационной погрешности // Информатизация и связь. 2019. № 4. C. 169-173. DOI: 10.34219/2078-8320-2019-10-4-169-173

9. Шестаков И.Н. Повышение точности позиционирования подвижных объектов с применением нескольких приёмных устройств СРНС на борту ВС // Научный Вестник МГТУ ГА. 2006. № 107. С. 180-189.

10. Ji C. An efficient adaptive clutter compensation algorithm for bistatic airborne radar based on improved omp application / C. Ji, M. Shen, C. Liang, D. Wu, D.-Y. Zhu // Progress in Electromagnetics Research M. 2017. Vol. 59. Pp. 203-212. DOI:10.2528/PIERM17060801

11. Kilani M.B., Gagnon G., Gagnon F. Multistatic radar placement optimization for cooperative radar-communication systems // IEEE Communications Letters. 2018. Vol. 22, iss. 8. Pp. 1576-1579. DOI: 10.1109/LCOMM.2018.2837913

12. Xu Z. A MLAT algorithm based on target pressure altitude / Z. Xu, D. He, Y. Tang, J. Li // IEEE International Conference on Mechatronics and Automation (ICMA). 2015. Pp. 1800-1804. DOI: 10.1109 / ICMA.2015.7237759

13. Webster T, Higgins T. Detection aided multistatic velocity back projection for passive radar // IEEE International Conference on Acoustics, Speech and Signal Processing (ICASSP). 2015. Pp. 5580-5584. DOI: 10.1109/ICASSP.2015.7179039

14. Webster T., Higgins T., Mokole E.L. Passive multistatic radar experiment using WiMAX signals of opportunity. Part 2: Multistatic velocity backprojection // Radar Sonar \& Navigation IET. 2016. Vol. 10, no. 2. Pp. 248-255. DOI: 10.1049/iet-rsn.2015.0021

15. Tong J. Cramér-Rao lower bound analysis for stochastic model based target parameter estimation in multistatic passive radar with direct-path interference / J. Tong, H. Gaoming, T. Wei, P. Huafu // IEEE Access. 2019. Vol. 7. Pp. 106761-106772. DOI: 10.1109/ACCESS.2019.2926353

16. Wang J. Target localisation in multistatic radar using BR, TDOA, and AOA measurements / J.Wang, Z. Qin, Y. Bi, S. Wei, F. Luo // The Journal of Engineering. 2019. Vol. 2019, iss. 19. Pp. 6052-6056. DOI: 10.1049/joe.2019.0128

17. Меркулов В.И., Садовский П.А. Оценивание дальности и ее производных в двухпозицонной пассивной радиолокационной системе // Труды СПИИРАН. 2018. № 1 (56). С. $122-$ 143. DOI: $10.15622 / \mathrm{sp} .56 .6$

18. Верба В.С., Меркулов В.И., Садовский П.А. Многодиапазонные радиолокационные системы. Проблемы многоцелевого сопровождения [Электронный ресурс] // Радиостроение. 2015. № 5. С. 37-51. URL: https://www.radiovega.su/jour/article/view/ 44?locale=ru_RU (дата обращения: 15.01.2020). DOI: 10.7463/rdopt.0515.0817948

19. Кузьмин C.3. Основы проектирования систем цифровой обработки радиолокационной информации. М.: Радио и связь, 1986. 352 с.

20. Васильев К.К., Павлыгин Э.Д., Гуторов А.С. Построение траекторий маневрирующих целей на основе сплайнов и фильтра Калмана // Автоматизация процессов управления. 2016. № 1 (43). C. 67-75.

21. Охрименко А.Е. Основы обработки и передачи информации. Минск: Воениздат, 1990. $180 \mathrm{c}$. 
22. Борисов Е.Г., Машков Г.М., Турнецкий Л.С. Повышение точности определения координат цели при реализации кооперативной обработки в многопозиционной радиолокационной системе // Радиотехника. 2013. № 5. С. 4-9.

23. Borisov E., Mashkov G., Fokin G. Experimental validation of multipoint joint processing of range measurements via software-defined radio testbed // 18th International Conference on Advanced Communication Technology (ICACT), Pyeongchang, 2016. Pp. 268-273. DOI: 10.1109/ICACT.2016.7423356

24. Шебшаевич В.С., Дмитриев П.П., Иванцевич Н.В. Сетевые спутниковые радионавигационные системы / Под ред. В.С. Шебшаевича. 2-е изд., перераб. и доп. М.: Радио и связь, 1993. $408 \mathrm{c}$.

25. Ширман Я.Д. Теоретические основы радиолокации: учеб. пособие для вузов. М.: «Советское радио», 1970. $560 \mathrm{c.}$

\section{СВЕДЕНИЯ ОБ АВТОРЕ}

Борисов Евгений Геннадьевич, доктор технических наук, доцент, главный специалист по реализации инвестиционных и научно-технических проектов Санкт-Петербургского государственного университета телекоммуникаций им. проф. М.А. Бонч-Бруевича, begspb1967@mail.ru.

Поступила в редакцию $\quad 06.02 .2020$

Принята в печать
19.03.2020
Received

06.02.2020

Accepted for publication
19.03.2020 